\title{
COMPLEMENTARY AND COMPETITIVE REGIMES OF ACCUMULATION: NATURAL RESOURCES AND DEVELOPMENT IN THE WORLD-SYSTEM
}

\author{
Astra Bonini \\ Department of Sociology \\ Johns Hopkins University \\ astra@jhu.edu
}

\begin{abstract}
During the post-war period, natural resource production has often been associated with peripheralization in the world-economy. This paper seeks to demonstrate that this association does not hold when examined from a long-term perspective, and explains the conditions under which natural resource production can support upward economic mobility in the world-system. First, this paper provides evidence that the production of cash crops and resource extraction has not always equaled peripheralization in the world-economy, as demonstrated by, among other things, the upward economic mobility of the United States, Canada, Australia and New Zealand during the nineteenth century. It then puts forth a new hypothesis that the existence of opportunities for raw material producing countries depends on whether the hegemonic regime of accumulation at a given time structures the economy in a way that is either complementary or competitive to the economic development of raw material producing countries. By examining the British centered regime of accumulation during the nineteenth century, we find that it was comparatively complementary to economic development in raw material producing countries whereas the twentieth century United States centered regime was comparatively competitive with raw material producers. Based on a comparison with Britain and the United States, the paper also suggests that China's increasingly central role in the world-economy may be comparatively complementary to economic development in raw material producing countries.
\end{abstract}

Key words: Resource curse, Natural resources, Terms of trade, Development

\section{INTRODUCTION}

From across the spectrum of development literature, the assumption is made that economic specialization in cash crops and natural resource extraction is a recipe for under-development and economic marginalization in the world-economy. In some circles this belief is referred to as the "resource curse," a hypothesis that low- and middle-income countries more often than not fail to use their resource wealth to generate economic growth (Auty 1993; 2001; Sachs and Warner 1995; 1997; 1999). Others speak of the belief in terms of a world division of labor and unequal exchange where poor countries provide rich industrialized countries with cheap natural resources, thereby perpetuating a world hierarchy of wealth in which raw material producers 


\section{JOURNAL OF WORLD-SYSTEMS RESEARCH}

remain at the bottom (Frank 1969; Amin 1977; Cardoso and Faletto 1979). The broadly accepted association between economic peripheralization and raw material-based economies is not surprising. One only has to compare the extraordinary economic growth of resource poor Japan and the East Asian Tigers (South Korea, Hong Kong, Taiwan and Singapore) during the second half of the twentieth century with the relatively slow growth of resource rich nations in Southeast Asia, Africa, and Latin America to emphasize this point. However, from a long-term perspective, the relationship between national wealth and economic concentration in such sectors as agriculture, mining and forestry has not always been negative. Consider for example that raw material wealth supported the upward economic mobility of the United States, Canada, Australia and New Zealand during the nineteenth century (Auty 2001; Wright and Czelusta 2007). Based on the historical record, it is possible that the negative socioeconomic conditions associated with raw material-based economies may be a late twentieth-century phenomenon rather than a general condition.

In this paper I examine this possibility using a world-systems perspective and conclude that, in fact, the production of cash crops and resource extraction does not equal peripheralization in the world-economy. Rather, I put forth a new hypothesis that the structure of the worldeconomy changes over time in ways that open up economic opportunities for raw materialproducing countries at some times, while limiting economic development in such countries at other times. Whether or not these opportunities exist at a given time, be it the nineteenth century, the twentieth century, or a point in the future, depends on whether the hegemonic regime of accumulation at that time structures the economy in a way that is complementary or competitive to the economic development of raw material-producing countries.

This paper is divided into three sections. The first section briefly reviews the hypothesis that raw material production is a cause of economic peripheralization, and then presents some evidence that refutes this argument. The second section examines the differences between historical regimes of accumulation and explains how the British regime of accumulation during the nineteenth century was comparatively complementary to economic development in raw material-producing countries, whereas the twentieth-century United States regime was more competitive with raw material producers. The third and final section discusses how this premise can be used to assess the implications of the changes we are seeing in the world-economy today for raw material-producing countries - namely the economic rise of China and increasing reports of "land grabs" and "neocolonialism" in resource rich countries.

\section{PERSPECTIVES ON RAW MATERIALS AND DEVELOPMENT}

In the body of literature that examines the relationship between natural resource wealth and economic development, there are two opposing perspectives about why countries that produce raw materials may be disadvantaged. There is significant disagreement between these two groups over causal mechanisms, but proponents of both perspectives agree that raw material producing countries are disadvantaged relative to manufactures producing countries. One side focuses on institutional level causes and argues that low levels of economic growth can be attributed to the way that natural resource wealth breeds bad state policies, ineffective governance, and corrupt and rent-seeking behavior. The other side focuses on structural causes like the declining terms of trade between raw materials and manufactured products and unequal exchange in international trade. 


\section{COMPLEMENTARY AND COMPETITIVE REGIMES OF ACCUMULATION 52}

Orthodox explanations of the disadvantages of raw material producing countries focus on state level policy failure. These views take Ricardo's (1817) comparative advantage thesis as their point of departure and reason that countries endowed with natural resources should take advantage of this gift from nature and trade their resources for goods produced in less resource endowed countries. Failure to convert natural resources into economic growth is explained by a lack of policies and institutions that facilitate resource based growth (Sachs and Warner 1995; 1997; 1999; Karl 1997). From this perspective, policies that slow exchange rate appreciation resulting from resource booms and minimize inflation in the non-tradable sector counter the phenomenon known as "Dutch disease" and help ensure that resource revenues support economic growth (Humphreys, Sachs, and Stiglitz 2007). ${ }^{1}$ Given that policy recommendations allegedly exist for avoiding the "resource curse," research from this perspective tries to explain why raw material rich states so often fail to implement these policies.

Corruption and rent seeking from political elites are popular explanations for policy failure. It is suggested that influential private actors and interest groups pressure state officials for access to funds causing resource revenues to dissipate across networks of patronage and corruption (Tornell and Lane 1999); in addition, state officials compete internally for control of resource revenues and the right to allocate rents (Ross 2001). Bad decision-making is another frequently cited reason for policy failure. The assumption is that windfall resource revenues induce 'irrational' behavior among state officials who are subject to social pressure to quickly improve national standards of living. Also, it is argued that this pressure results in uncoordinated, shortsighted spending and that the sheer amounts of money created during resource booms reduce the care with which policymakers handle seemingly unlimited funds (Auty 1993; Mitra 1994). While such policy failure arguments are frequently used, their utility is suspect since it is unclear that levels of rent seeking and corruption are higher in natural resource rich countries than in resource poor countries; or that resource rich countries with high levels of corruption have experienced lower growth rates than other resource rich countries. Indonesia, for example, has consistently ranked as one of the most corrupt nations in the world and yet has experienced one of the highest levels of economic growth among raw material producing countries over the past forty years. Perhaps a bigger weakness of this institutional perspective, however, is that it assumes that once state level policy failures are corrected, development will follow. This perspective ignores external structural constraints on development that have little to do with internal institutions and policies.

The other side of the development debate focuses on structural constraints, but the conclusion is the same: specialization in cash crops and resource extraction are bound to lead to underdevelopment and peripheralization. This is because the world-economy consists of a division of labor that places raw material producing countries in weak negotiating positions visa-vis the industrialized core and results in systems of unequal exchange in trade (Baran 1957;

\footnotetext{
${ }^{1}$ The term 'Dutch disease' became popular when natural gas was discovered in the Netherlands in the 1960s and the value of the guilder rapidly appreciated, leaving Dutch manufactured goods uncompetitive on the international market. As a general concept, 'Dutch disease' affects resource exporting countries when a boom in resource exports, set off by new domestic discoveries or increasing world prices, results in increased income in the resource sector and an accompanied increase in demand for domestic non-tradable and tradable goods and services (Corden and Neary 1982; Corden 1984). The prices for non-tradable goods rise to meet demand, but increased demand for tradable goods like manufactures and agricultural products are met by increased imports since prices are determined internationally. This process generates a tendency towards de-industrialization (or de-agriculturalization) as labor and capital move from the tradable sector into the more profitable resource-based and non-tradable sectors.
} 


\section{JOURNAL OF WORLD-SYSTEMS RESEARCH}

Furtado 1964; Frank 1969; Amin 1977; Cardoso and Faletto 1979). Furthermore, as Raul Prebisch and Hans Singer contended in independent studies in 1950, the terms of trade between raw materials and industrial products have a tendency to decline such that countries exporting raw materials face increasing prices for imports of manufactured goods. This hypothesis, which became known as the Prebisch-Singer thesis on the declining terms of trade, has been used to explain the twentieth century divergence in wealth between rich and poor countries on the grounds that poor countries face ever increasing prices for imported manufactured products because of their specialization in raw material exports. This is a legitimate claim since, as Figure 1 shows, there is evidence of the decline during the twentieth century (Grilli and Yang 1988; Maizels, Palaskas, and Crowe 1998; Cashin and McDermott 2002).

Figure 1: Terms of Trade for Primary Products, 1900-1986

$(1900=100)$

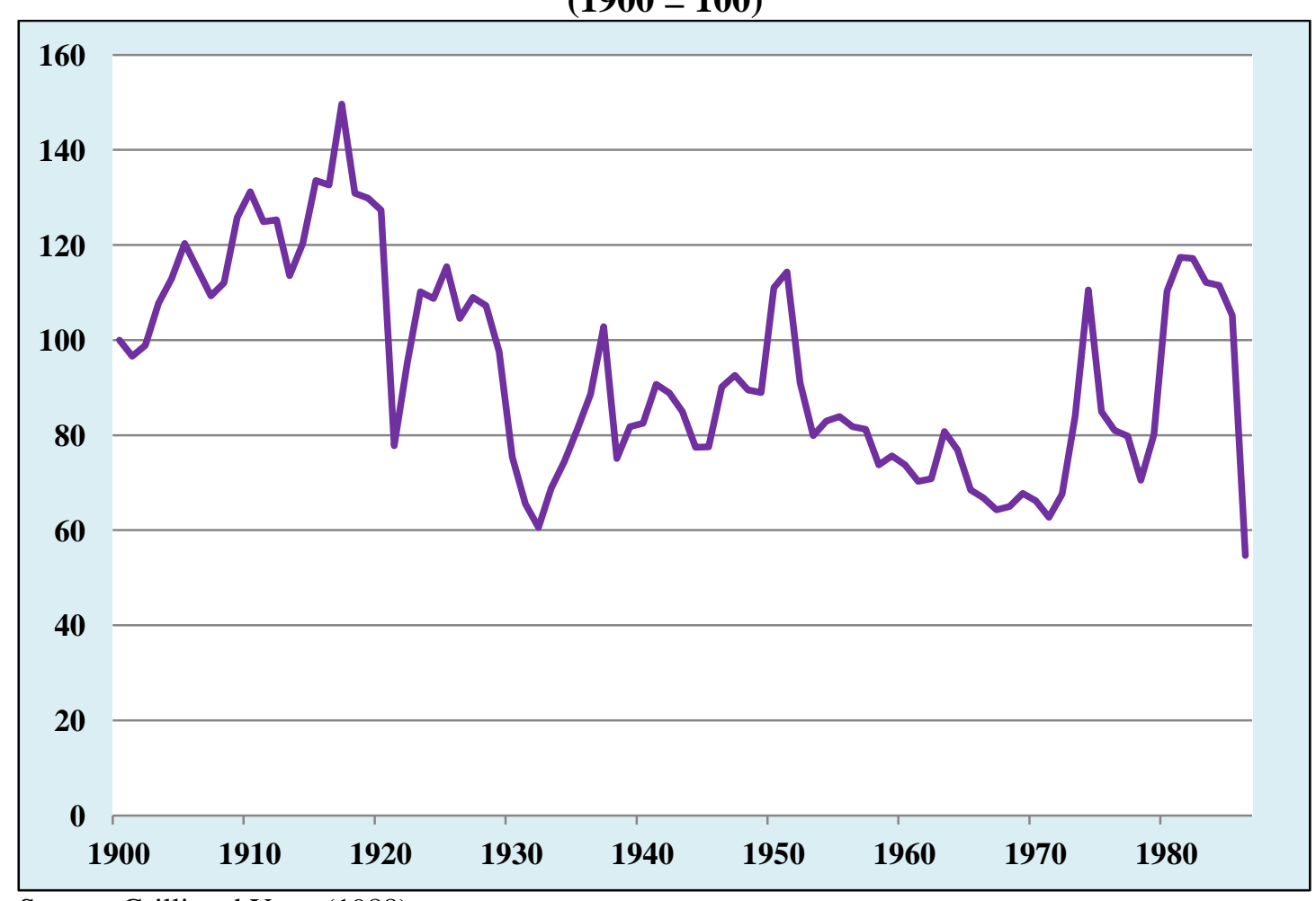

Source: Grilli and Yang (1988).

Figure 1 shows that, although there were ups and downs, the overall trend was that prices of raw materials were dropping relative to manufactured goods for most of the twentieth century, making imports of manufactured goods increasingly expensive for raw material exporting countries. This figure only shows the trend from 1900 to 1986; a time period during which the terms of trade decline was about 0.5 percent per year for raw material exporting countries. However, after 1986 additional studies estimate that the decline increased to between two percent and four percent annually through the 1990s (Maizels et al. 1998; Cashin and McDermott 2002).

While there were clearly structural disadvantages for raw material producing countries during most of the twentieth century, it is not at all clear that this means economic concentration 
in raw material sectors can be equated with underdevelopment as a general rule outside of the particular conditions of the twentieth century. Rather, I believe that what appears to be a structural linkage between raw material production and peripheralization is merely an outcome of the particular structure of the twentieth century world-economy. There is evidence in support of this claim. For one thing, the terms of trade between raw materials and manufactured goods has not always been declining. As Figure 2 shows, the terms of trade were actually moving in favor of raw materials for most of the nineteenth century. ${ }^{2}$ In fact, between 1798 and 1913, Imlah (1950) found that the terms of trade for countries exporting goods to Britain, which were predominantly raw materials, improved by an average of 0.82 percent per year. Sarkar's (1986) study produced similar results to Imlah's showing that the terms of trade improved by an average rate of 0.87 percent per year between 1801 and 1881 for raw material exporters. By 1881 this meant that raw material producers were able to purchase twice the amount of imported manufactured goods as they had been able to purchase in 1800 with their export revenue (Cypher and Dietz 2004).

Figure 2: Terms of Trade for Primary Products 1798-1900

$(1798=100)$

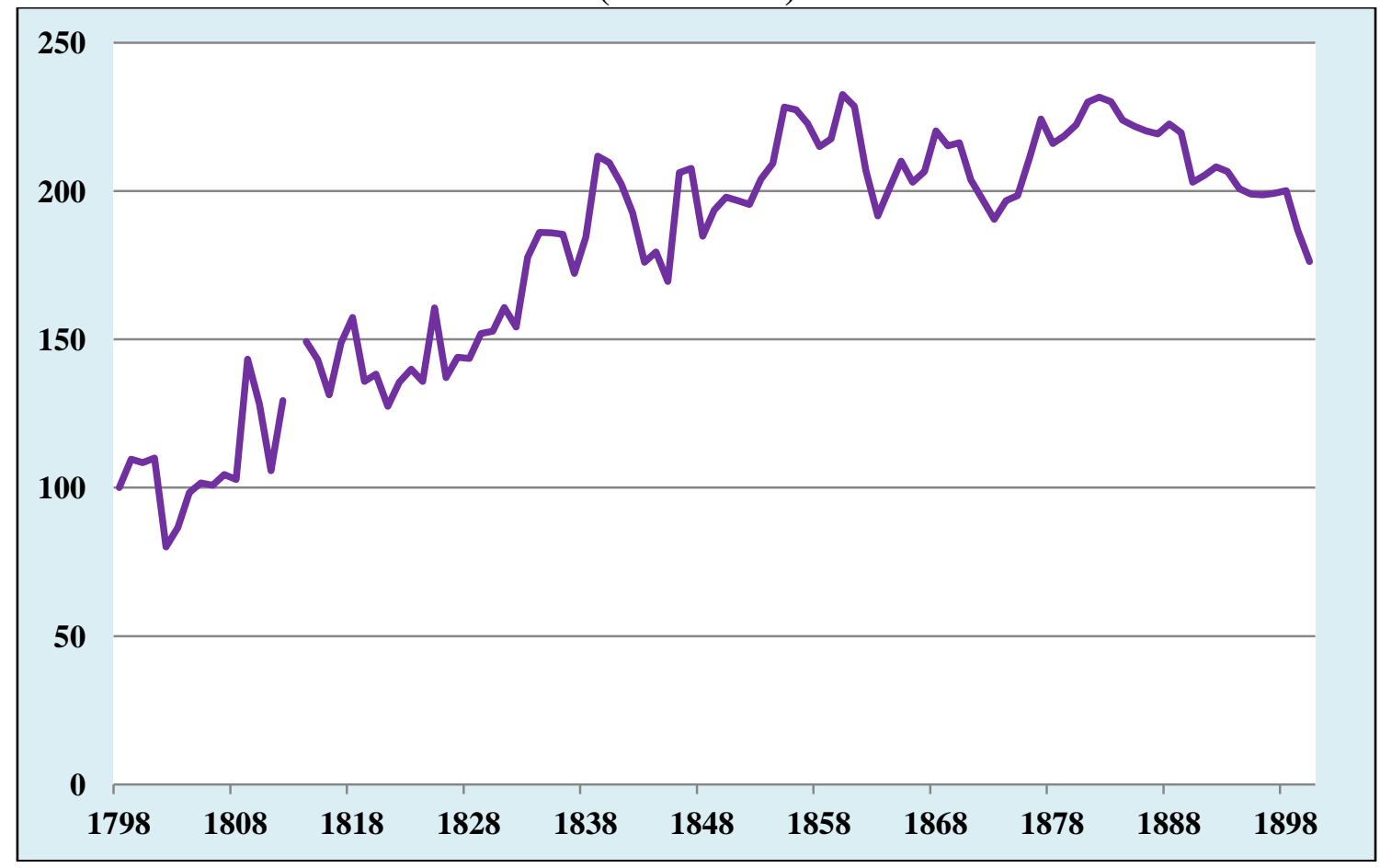

Source: Imlah (1950).

\footnotetext{
${ }^{2}$ This trend is actually based on Britain's import and export data, but this data set is generally accepted as representing the terms of trade for primary products against manufactured goods since Britain's exports were predominantly manufactured goods and imports were mainly raw materials (Prebisch 1950; Sarkar 1986).
} 


\section{JOURNAL OF WORLD-SYSTEMS RESEARCH}

There is also evidence that raw material rich countries were able to take advantage of the increasing terms of trade. Figure 3 shows that in 1870, raw materials made up the bulk of exports from the United States, Canada, New Zealand and Australia while Britain exported only a minimal quantity of raw materials. Despite this specialization, however, these raw material exporting countries were some of the wealthiest countries in the world at the time. In fact, Australia's per capita GDP actually exceeded that of Britain in 1870 (Maddison 2006).

Figure 3: Raw Material Exports as \% of Total Exports in 1870

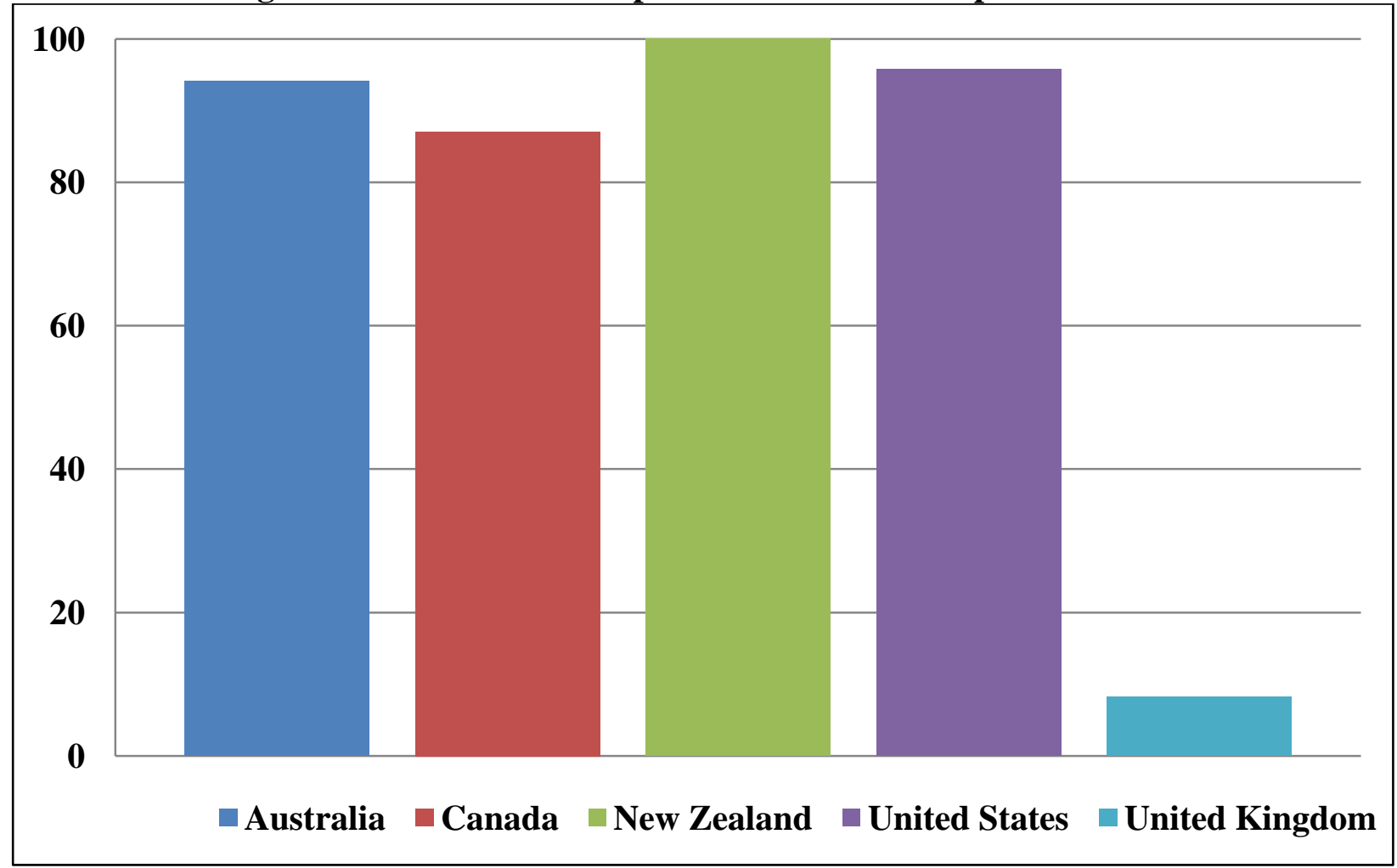

Source: Compiled data set based on British Parliamentary Papers (multiple years).

While the precision of nineteenth century trade and income data vary, the above patterns at least indicate that world economic conditions during the nineteenth century may have been better for raw material producers than conditions during the twentieth century. The widely accepted linkage between raw material production and peripheralization seems to be related to the twentieth century world-economy and does not seem to be a generalizable relationship outside of this particular time period. This raises the question of why raw material producing countries faced development challenges during the twentieth century whereas conditions were more positive for development during the nineteenth century.

\section{COMPLEMENTARY AND COMPETITIVE REGIMES OF ACCUMULATION}

Assessing how economic opportunities have changed during the nineteenth and twentieth centuries for countries specializing in cash crops and raw material extraction requires an understanding of how the macro-economic conditions of the capitalist world-economy have changed during this time period. Giovanni Arrighi's 1994 book, The Long Twentieth Century, 
includes a useful vantage point for identifying how these conditions have changed. Arrighi develops a framework showing how the history of capitalism has been characterized by a succession of hegemonic powers that have each defined and made efforts to control regimes of capital accumulation on a world scale. Each successive "regime of accumulation" has taken advantage of periods of crisis and change in the world-economy to restructure and reorganize the world system to its advantage. "The strategies and structures through which these leading agencies have promoted, organized, and regulated the expansion or the restructuring of the capitalist world-economy is what we shall understand by regime of accumulation on a world scale" (Arrighi 1994:9). The most recent such regimes include: the British-centered regime of the nineteenth and early twentieth centuries; the United States-centered regime of the mid- to late twentieth century; and an emerging 'new' regime that will likely be centered in East Asia, most probably in China. During the nineteenth century, Britain structured the world-economy to the advantage of the British economy and during the twentieth century the United States used its position of power to structure the world-economy to reflect the economic and political interests of the United States.

Arrighi's framework is useful for examining how the structure of the nineteenth century British-centered world-economy may have opened up spaces for the development of raw material producing countries while the structure of the twentieth century United States-centered economy limited such opportunities. Based on a comparison between the United States and Britain, we can also use this framework to make informed forecasts about the structural opportunities and limitations natural resource rich countries may face in the twenty-first century with a China-centered regime of accumulation.

What were the differences between the British and United States regimes of accumulation in terms of their relationships to raw material producing countries? Broadly speaking, the British regime of accumulation was complementary to raw material producing countries while the United States regime was competitive with these countries. The British maintained their position as the center of the world-economy using trade and investment tools that were not only beneficial to the domestic economy, but also opened up development opportunities for countries specializing in cash crops, particularly cotton and grain which faced significantly lower British trade barriers than manufactured goods. Even prior to the repeal of the Corn Laws in 1846 (at which point the duties on almost all imports were abolished); duties on critical raw material inputs were significantly lower than duties on manufactured goods. For example, in 1839 duties on raw cotton, wool and corn imports were on average only 6.9 percent (Imlah 1958:148). Such low duties stand in stark contrast to duties on manufactured goods which were on average as high as 40 percent in 1840 (The House of Commons 1840:6). Britain used unilateral policies of free trade to promote domestic economic growth, first exporting industrial goods to the rest of the world in exchange for raw material inputs, and later serving as the world's financial and commercial entrepot, to secure its position as the center of the world-economy. "A large and growing number of states and territories were thus 'caged' in a world-scale division of labor that strengthened each one's interest in participating in the British-centered global market, the more so as that market became virtually the sole source of critical inputs and sole outlet for remuneratively disposing of outputs" (Silver and Arrighi 2003:335).

In addition, the structure of business organization in Britain was highly decentralized and differentiated, making it impossible for British corporations to control all aspects of global production. This was to the advantage of raw material exporting countries. Take the case of 


\section{JOURNAL OF WORLD-SYSTEMS RESEARCH}

cotton as an example. Textile factory owners rarely attempted to vertically integrate the textile production process by incorporating raw cotton production and shipping into their business activities. Instead, "they were content to rely upon the Liverpool market for their raw material and had virtually no interest in its ultimate source so long as it arrived regularly and cheaply" (Farnie 1979: 16). As a result, unlike the vertically integrated commodity chains that emerged during the twentieth century; the cotton trade involved a myriad of actors operating at all nodes of the textile commodity chain including planters, merchants, brokers and spinners. The structure of the cotton trade was to the advantage of raw cotton exporting countries because they were able to retain a large share of the value added along the commodity chain vis-a-vis merchants, brokers and spinners. In the United States the bulk of the value of raw cotton was retained by the cotton planters while merchants and brokers in turn received small percentages of the final sale price. Ellison (1968) provides accounts of the cotton trade from 1816 where over 60 percent of the sale price of the raw cotton was retained by the cotton planter in the United States (245).

Essentially, Britain did not compete with raw material producing countries to control the production of raw materials but rather specialized in manufacturing and in those activities that facilitated the trade of raw materials for manufactured goods. Britain's wealth was linked to manufacturing and commercial and financial activities and was not threatened by the development of countries specializing in raw material sectors. In fact, Britain made efforts to increase development in countries that provided its domestic economy with natural resources. To accommodate the expansion of the domestic manufacturing sector, the British regime provided raw material producing countries with access to the means of raw material production (capital, technology and knowledge). For example, Eric Hobsbawm draws attention to the long-term industrial benefits countries gained from railway iron and machinery exported by British industry even though the British benefitted disproportionately at the time of trade (1975:39). Colonies and countries committed to exporting primary products saw virtually unlimited exports and credits under the British regime and had very little incentive to industrialize given that the terms of trade, at least before 1914, seemed to be running in favor of raw materials (Hobsbawm 1987:64$65)$.

The imperial aspects of Britain's hegemony and the series of colonial wars fought during the late nineteenth and early twentieth century most certainly did affect developmental outcomes in colonial territories. Hence, the British regime of accumulation was not necessarily complementary to all countries that were rich in natural resources. Just to be clear, however, the procurement of raw materials was never the primary motivation for Britain's colonial expansion. As Paul Bairoch (1993) has shown, most of the raw materials consumed by industrial centers in Europe during the nineteenth century came from other developed countries not from southern colonies. As late as the eve of World War I developed countries acquired 98 percent of their metal ores, 80 percent of their textile fibres, and 100 percent of their energy resources from the developed world (Bairoch 1993:67-8). For example, during the nineteenth century Britain's largest import, raw cotton, came predominantly from the United States which supplied on average about 67 percent of Britain's cotton imports between 1800 and 1883 (Ellison 1968: 86). From the perspectives of the colonies, however, raw material exports to Britain and other developed countries were of the utmost economic importance. Exports of primary products represented more than ninety percent of their total exports, almost all of which were to developed countries (Bairoch 1993:68). Because these territories have long suffered from underdevelopment, and because many of these countries rely to a large extent on raw material 
exports, a link is frequently drawn between their raw material economies and underdevelopment. To the contrary, Britain and other developed countries procured most of their raw materials from white-settler colonies like Australia, Canada, the United States and New Zealand leaving the raw materials in other colonies relatively underexploited. Of course there were some raw materials that were not available in the developed world-including rubber, natural fertilizers like guano, and tropical crops like coffee and tea-but these resources represent a small portion of total raw material imports to the developed world (Bairoch 1993).

If the conquest of colonial territories was not primarily for procurement of raw materials, it was economically necessary from the perspective of Britain because it helped to facilitate global trade. According to Eric Hobsbawm (1987), the primary purpose of colonization for Britain was securing control over various land and sea zones that were essential for the maintenance and expansion of Britain's world-wide web of commercial and maritime interests (67). This required the establishment of a global network of coaling stations to support steam powered shipping, along with control of sea routes to the east like the Suez Canal. In particular, access to India was critical to British power and required

control not only over the short sea-routes to the subcontinent (Egypt, the Middle East, the Red Sea, Persian Gulf and South Arabia) and over the long sea-routes (the Cape of Good Hope and Singapore), but over the entire Indian Ocean, including crucial sectors of the African coast and its hinterland. British governments were keenly aware of this. It is also true that the disintegration of local power in some areas crucial for this purpose, such as Egypt (including the Sudan), drew the British into establishing a much greater direct political presence than originally intended, and eventually into actual rule. (68)

In this sense, Britain's geo-political interests during the nineteenth and early twentieth centuries did have a lasting impact on the socio-economic structures of colonial territories that may account for the relative differences in development outcomes between major raw material producing countries like the United States and Australia, and those territories that were exploited mostly for their strategic placement along Britain's trade routes.

In contrast to Britain, the U.S. development path included an approach to trade and investment that increased the likelihood of underdevelopment in countries specializing in cash crops and raw material extraction. The U.S. regime is conceptualized as having a competitive relationship with the rest of the world-economy and in particular with raw material producing countries. With the continental size of its economy and the vertically integrated, transnational structure of its corporations; the United States could use means other than unilateral free trade policies to position itself at the center of the world-economy (Silver and Arrighi 2003:339-340). The United States has an expansive territory and abundant natural resources. As Stephen Bunker and Paul Ciccantell (2005) have pointed out, these factor endowments helped the United States evolve into a major raw material producer and a center of technological innovation in raw material sectors. The productivity of the U.S. raw material sectors subsequently supported the country's emergence as a world leader in manufacturing (Wright 1990:658). At the beginning of the twentieth century, the United States was a globally competitive producer of commodities ranging from oil and grain to copper and cotton (Smith 1919:288-9), and recent data indicate that raw materials remain a large source of U.S. exports, with grain being among the top exports for much of the late twentieth century (OECD). While raw material production has supported the 


\section{JOURNAL OF WORLD-SYSTEMS RESEARCH}

growth of the U.S. economy, the high productivity of raw material sectors has increased competition among less productive raw material exporting countries for access to markets and intensified the decline in the terms of trade for those countries. Taking the case of grain as an example, subsidies and high levels of productivity have enabled U.S. grain producers to outcompete other grain producing countries in the world market because they are able to export excess grain at artificially low prices (Atkin 1992; Winders 2009). Cheap American grain exports have been associated with the economic decline of many lower income countries with large agricultural sectors (McMichael 2004:56).

The United States remains a major producer of many agricultural and mineral commodities, but levels of per capita raw material consumption are high enough that the United States also imports large quantities of most raw materials. Increasing U.S. imports of raw materials have not, however, translated into development opportunities for raw material exporting countries. U.S. corporations' vertically integrated multinational structures have enabled them to compete in all aspects of raw material production in locations around the world (Chandler 1990). This has reduced opportunities for other countries to benefit from the exploitation of their national resources. For example, U.S. oil companies have been able to exploit foreign oil reserves through favorable investment agreements. The contracts established are designed primarily by U.S. oil companies and give a minimum in profits to the host government or territory. As an example, U.S. oil companies operating in Venezuela in the 1930s were making five times more profit per barrel of oil extracted than the Venezuelan government (Philip 1994:60). Even after many countries nationalized their oil production during the 1970s, U.S. oil companies retained their technological advantage in exploration and drilling as well as their relatively high capacity to transport, refine and market crude oil. As recently as 2009, for example, 20 percent of the world's crude oil was refined in the United States, more than in any other single country. On the other hand, Saudi Arabia, the world's largest producer of crude oil, only refined 2.3 percent of the world's crude. ${ }^{3}$ Rather than supporting the development of other countries as independent raw material producers by providing access to its markets, capital, technology and knowledge, the United States has appropriated a large portion of the value added in foreign raw material production while also competing in raw material export markets. Essentially, the U.S. economy developed along a raw material-intensive path organized around large, transnational corporations that specialized in all aspects of raw material production and trade. This economic structure left little space for the emergence of competitive raw material sectors in other countries.

Just like the geopolitically motivated exceptions to Britain's complementary relationship during the nineteenth century, there are exceptions to the general norm of the "resource curse" during the twentieth century that can be traced to U.S. geopolitical interests. Many of these exceptions can be linked to Cold War strategies of outcompeting the Soviet Union in terms of global influence by offering economic aid and investment relationships to those developing countries that were either sympathetic to U.S. interests or strategically located (McMichael 2004: 48). Take for example the case of Indonesia which is frequently referenced as a raw material producing country that did not succumb to the "resource curse" during the twentieth century. Andrew Rosser (2007) associates Indonesia's developmental exceptionalism to its strategic location during the Cold War, made possible by Suharto's capitalist friendly development policies. During the 1970s, the United States was engaged in the Vietnam War and there was

\footnotetext{
${ }^{3}$ Calculations based on data from the BP Statistical Review of World Energy 2010 (http://www.bp.com/).
} 
widespread fear that communism might spread throughout Southeast Asia. This resulted in a series of U.S. initiatives aimed at incorporating countries like Indonesia into the capitalist sphere of influence (50). When Suharto gained power, the United States quickly took advantage of his capitalist leanings with offers of aid and assistance in consolidating his rule. The developmental impacts in Indonesia cannot be understated. Indonesia became one of the top recipients of financial aid in the world and remained so until the end of the Cold War in the late 1980s and early 1990s (52). At the same time that oil and gas revenues were declining for many producing countries, large sums of aid were pouring into Indonesia because of its strategic geopolitical significance, making Indonesia an exception to the general rule of the "resource curse."

Of course more often than not, and particularly since the end of the Cold War, intervention by the U.S. government in raw material producing countries has privileged its economic interests over these countries' economic development. This is particularly the case with oil rich countries where the U.S. military supports U.S. oil companies' access to foreign oil. For example, Chalmers Johnson (2004) draws attention to the U.S. push to establish military bases throughout Central Asia, where oil abundance has attracted U.S.-based oil companies. Johnson suggests that the U.S. military followed these companies to nations bordering the Caspian Sea specifically to protect private capitalist interests (169). The Caspian oil basin is the last large, undeveloped oil and gas field in the world, and is thus of great interest to oil consuming nations, namely the United States and increasingly China. U.S. companies including Chevron, Unocal, Amoco and Exxon all expressed great interest in building a pipeline to exploit these resources, but it was not until the United States began building a complex of military bases in the involved countries - Afghanistan, Kyrgyzstan, Pakistan and Uzbekistan - that they were able to successfully negotiate their investments (172-3). The link between the U.S. military and access to foreign oil is not limited to this case either. The war in Iraq has been repeatedly linked to oil interests and, in fact, recent drilling agreements with the Iraqi government position U.S. oil companies at the forefront of the race for oil revenues (Kramer 2011).

In comparison to Britain's overseas military activities during the nineteenth century which were primarily aimed at protecting trade routes, U.S. activities are in many cases directly related to procuring raw materials or to protecting the investments of U.S. raw material producing companies. In sum, while the trade and investment policies that Britain adopted during the nineteenth century provided opportunities for economic development in raw material rich countries, the trade and investment policies that enabled the U.S. economy to maintain its leading position in the world-economy during the twentieth century limited opportunities for the upward mobility of other raw material rich countries.

\section{IMPLICATIONS FOR THE FUTURE}

Let us now turn to the contemporary relationship between development and specialization in raw material sectors. Is it possible that the structure of the world-economy could once again become complementary to raw material producing countries? In the opening years of the twenty-first century, the global economy has been characterized by a boom in demand and prices for raw materials; particularly oil, gas and metals, but also agricultural commodities. ${ }^{4}$ This demand has

\footnotetext{
${ }^{4}$ The United Nations Conference on Trade and Development (UNCTAD) defines 2002 as the start of this boom in commodity prices. Between 2002 and 2006 world commodity prices for non-fuel minerals, ores and metals increased 220 percent, and crude oil prices increased 158 percent. Before 2002 most of these commodities had
} 


\section{JOURNAL OF WORLD-SYSTEMS RESEARCH}

been accompanied by a surge of investments in mineral exploration and cropland expansion around the globe. The current wave of investment stands in stark contrast to past waves because most of the recent growth in demand has been from the global South and China in particular. In 2005, China alone accounted for 29 percent, 66 percent and 25 percent of the growth in world demand for oil, copper and nickel respectively (UNCTAD 2007:89). China's investments have raised alarm from journalists, policy makers, academics and activists about the potential for a wave of "neocolonialism" and "land grabs" across the resource rich global South and in particular in Africa (see Geisler in this issue). As just one example, U.S. Secretary of State Hilary Clinton recently warned African countries to guard against the intentions of Chinese investment at a press conference in Zambia (Wonacott 2011). China is frequently depicted as the latest in a series of imperial powers seeking to plunder the natural endowments of poor countries while gaining access to new markets for cheap manufactured goods. However, it is not clear that the story is altogether negative, since some view China's raw material demand as an opportunity for development in resource rich low income countries (Taylor 2006; Sautman and Hairong 2008). A comparison of China's contemporary interactions with raw material producing countries with those of nineteenth-century Britain and twentieth-century United States can shed light on this issue from a longer-term structural perspective than is typically used to portray the impact of China's search for natural resources on developing countries.

Britain and the United States clearly had very different types of relationships with raw material producing countries, and these relationships resulted in very different economic opportunities for the latter's development. There are some indications that the structure of the world-economy may once again become complementary to the development of raw material producing countries, despite critiques of China's scramble to procure natural resources around the world. As Figure 4 shows, the commodity boom at the beginning of the twenty-first century resulted in a reversal of the declining terms of trade for raw materials that characterized the twentieth century. This supports the possibility of a long-term reversal of the terms of trade in favor of raw material producing countries.

Even with the 2008 financial crisis, which brought a sharp drop in raw material prices, the overall trend has been positive since 1999 for all except agricultural raw materials. In 2009, raw material prices stabilized and began increasing once again. This indicates that the positive trend in commodity prices may be robust, particularly for non-renewable resources like fuels and metals. China's demand for fuels and metals has accounted for much of the recent growth in world demand for metals like copper, lead, nickel, steel, tin, and zinc as well as for agricultural products (IMF 2006). This demand has helped to increase prices for raw material exporters and is transforming the terms of trade to move in favor of raw material exporters.

experienced declining prices (UNCTAD 2007a:7). Commodity prices declined in 2008 during the financial crisis, but prices began to rise again in 2009 (UNCTAD 2009:6). 
Figure 4: Recent Terms of Trade for Fuel, Food, Non-food Agriculture and Metals 1992 $2011(1992=100)$

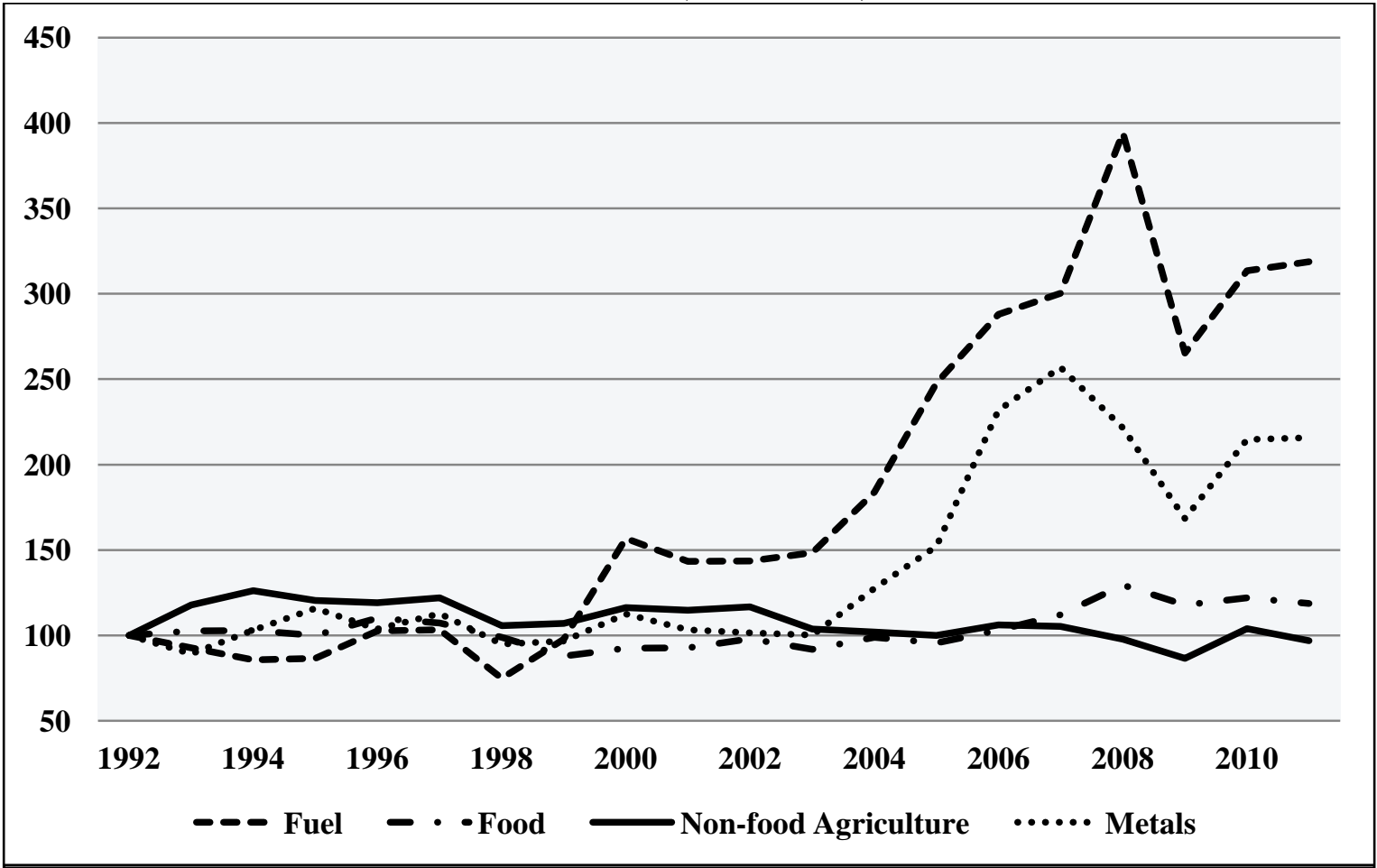

Source: Author's calculations based on IMF (2011).

Beyond the impact China is having on the terms of trade for raw materials, I would argue that a China-centered regime of accumulation would be more similar to the British regime than to the U.S. regime, and therefore relatively complementary to raw material producers. First, China's economic specialization in consumer goods manufacturing and position as the new "workshop of the world" is similar to Britain and will likely require liberal trade policies on raw material imports to secure adequate supplies of raw material inputs for the economy. In terms of business structure, China is similar to Britain in that the small scale and decentralized nature of the manufacturing sector in China reduces China's bargaining power against raw material suppliers. For example, recent negotiations over prices for iron ore imports have shown how the small scale of steel manufacturing in China has limited steel manufacturers' power in price negations with iron ore suppliers. In 2008, after months of bargaining over iron ore prices, Australian iron ore producers Rio Tinto PLC and BHP Billiton Ltd. negotiated an 85 percent increase in the benchmark price of iron ore. This victory for iron ore producers came soon after Brazilian mining company Vale negotiated a similarly attractive iron ore price increase (Matthews 2008). Iron ore producers are able to take such hard line positions in iron ore price negotiations because they are dealing with a competitive steel sector in which individual steel firms have little leverage in the negotiations. Finally, like nineteenth century Britain, China has a capital surplus and has offered loans to raw material producers at very attractive terms (Sautman and Hairong 2008; Taylor 2009). These loans typically support infrastructure projects which are built by Chinese construction companies at a low cost rather than by higher cost Western companies. Chinese construction firms have completed much of the construction work associated 


\section{JOURNAL OF WORLD-SYSTEMS RESEARCH}

with these infrastructure projects, which is part of the attraction for the Chinese government in making these loans. While this arrangement has been criticized for not maximizing the use of local labor, the Chinese construction firms' costs are low relative to those of Western firms. Thus, for example, oil producing countries are able to improve their infrastructures at a lower cost than would have been possible under Western investment.

Most importantly though, China's economic specialization in labor-intensive manufacturing is complementary to natural resource rich countries because China's wealth does not depend on its ability to crowd out raw material producers. Rather, China's manufacturing economy creates demand for raw materials and provides raw material exporters with access to foreign exchange and cheap manufactured goods. China's demand for raw materials is already affecting countries that are rich in natural resources. For Australia, Indonesia and Brazil, China is the largest market for exports of iron ore and timber, and Sudan exports the majority of its oil to China. Zambia's copper mines were in decline for most of the 1990s, but China now offers a growing market for copper and Zambian mines are thriving. China's imports of raw materials offer a welcome market for many countries that suffered from years of declining commodity prices, and there is little sign that the demand will decline anytime soon. All signs indicate that China is at the early stages of its raw material consumption growth and that growing demand for these commodities is not a temporary spurt such as those that resulted in the commodity price shocks of the 1970s and 1990s (Kaplinsky 2010:103). To the contrary, it is likely that rising prices and demand for most commodities will be sustained for some time-much to the benefit of raw material producing countries.

This brings us to the question of whether China's geopolitical interests might create limitations for some raw material producing countries despite the general trend toward complementarity in trade relationships. There are signs that China treats certain raw material producing countries with preference over others based on political interests. This is primarily linked to the recognition of Taiwan as either an independent state or a province of China. China has threatened that it will cut ties to any state that establishes diplomatic relations with Taiwan and so Taiwan is officially recognized by very few states (Taylor 2009:28). Oil rich Sao Tome and Principe is one country that recognizes Taiwan, and while this has resulted in large aid transfers from Taiwan, China has looked elsewhere for oil investment opportunities.

In terms of military intervention, however, it is likely that China will not be as active in using force and territorial conquest to support economic expansion as was the case with Britain and the United States. This expectation is based in large part on Arrighi's assessment of the differences between the European and East-Asian paths to development as laid out in Adam Smith in Beijing (2007). Arrighi contends that, in contrast to the Western (European) style of inter-state relations which have been based on military competition and territorial expansion outside of Europe, East Asian inter-state relations have been based around national economy building and an absence of overseas empires (315-17). Of course these two divergent development paths came together when East Asia was incorporated into the European system during the nineteenth century. Arrighi writes that the result was a "hybrid political-economic formation that has provided a particularly favorable environment for the East Asian economic renaissance" (313). Speaking to popular fears and expectations for a new Cold War between China and the United States, Arrighi contends that it would be in China's best interest not to follow the military path of the West, but rather to wait for the United States to expend its dwindling resources on its military and financial commitment to the war on terror, and in the 


\section{COMPLEMENTARY AND COMPETITIVE REGIMES OF ACCUMULATION 64}

meantime expand its national market to win allies and create a new market based global order to replace the European one that is based on force (312). If Arrighi is correct, there is little reason to be concerned that China has plans to use force or territorial expansion to gain access to raw materials. Rather, China's interest lies in expanding trade and providing an alternative to Western military style dominance in the global system. This is evident when we observe that "China has played a leading role both in rerouting the Southern surplus to Southern destinations and in providing neighboring and distant Southern countries with attractive alternatives to the trade, investment, and assistance of Northern countries and financial institutions" (382). However, as with all things concerning China, it is too early to state emphatically that China will be able to maintain this approach instead of the other possibility that the East Asian path converges toward the Western approach of global domination via force and territorial expansion.

\section{CONCLUSION}

The world-economy has presented very different conditions for raw material rich countries at different points in time since the beginning of the nineteenth century. Theories and policies that are based on the assumption that raw material production is equivalent to peripheralization in the world-system, or that there is a "resource curse" whereby countries that produce manufactured goods will always outcompete countries that produce raw materials incorrectly assume that the structural conditions within which countries compete are static. The structure of the worldeconomy is shaped by the interests of hegemonic regimes of accumulation that have changed over time - Britain, the United States and China are diverse countries with significant economic, social and geographical differences. ${ }^{5}$ The innovations these countries have used to attain and maintain their positions at the center of the world-economy and to excel in a system of capitalist "creative destruction" reflect these differences. Britain, a small island nation with higher productivity in textiles than any other country at the time created a world wide web of trade and opened its borders to receive flows of raw materials from around the world. The United States took advantage of Britain's demand for raw materials during the nineteenth century and went on to become one of the world's most innovative centers of raw material extraction and agricultural productivity during the twentieth century. The United States innovated government support and oligopolistic business structures to maximize its revenues from global raw material production and consumption, effectively crowding out other raw material producers. China has maximized its extreme competitive edge in labor-intensive manufacturing. In addition, the business structures that make Chinese manufacturing flexible and competitive also shift the power in negotiating the terms of trade and investment toward raw material producers.

These shifting innovations and structures have had pronounced impacts on opportunities for economic advancement in raw material producing countries. The terms of trade patterns shown in section one support the view that there is has been a general trend in which countries

\footnotetext{
${ }^{5}$ This paper treats China as an emerging world hegemon even though this assumption is contentious. I do not argue that this is the only path the world-economy could take; it is merely the path I chose to consider in this analysis as a means of assessing the economic effects of China's rise on raw material producing countries.
} 


\section{JOURNAL OF WORLD-SYSTEMS RESEARCH}

producing raw materials were more likely to advance economically during the nineteenth century and at the beginning of the twenty-first century than they were during the twentieth century. However, the conclusion to this analysis is not that all raw material producing countries will achieve rapid upward economic mobility during the twenty-first century, just as all raw material producing countries were not upwardly mobile during the nineteenth century. This analysis merely points out that the odds of upward mobility are better when the world-economy is structured by a complementary regime of accumulation like that of Britain or China than they are under a competitive regime like that of the United States. In reality, there are numerous factors that determine a given country's economic outcome at a specific time in addition to the structure of the world-economy, including characteristics of specific types of raw materials, national social and economic structures and institutions, and geo-political relationships. This paper has clearly not given adequate attention to other intervening factors because the goal was to present variations in the structure of the world-economy and the implications for this structure on raw material producing countries. However, that does not mean that these issues are any less important.

I would like to conclude by restating the main point of this research - that raw material production should not be viewed as an economically inferior activity to manufacturing. The structure of the world-economy is not static, and it presents different types of economic opportunities depending on the characteristics of the leading regime of accumulation in the world. Hence, inequalities in the wealth of nations cannot be addressed by merely transitioning low income countries out of raw material industries, particularly at times like we are seeing in the twenty-first century when the world-economy provides these countries with opportunities to accumulate wealth through complementary trade relationships. Whether or not cash crops or extractive industries are peripheral activities is a question that depends at least in part on how the world-economy is structured and whether it is in the interest of hegemonic powers to adopt trade and investment policies that are complementary or competitive to raw material producing countries. What is clear is that raw material wealth cannot be equated with peripheralization in the world-economy across time and space.

\section{ACKNOWLEDGEMENTS}

I would like to thank participants in the 2010 Political Economy of the World-System Conference at Florida Atlantic University for their questions and feedback on an earlier version of this article. In particular Farshad Araghi and Marina Karides provided valuable comments on previous drafts. I am also grateful to the late Giovanni Arrighi for his encouragement and guidance on this project, and to Beverly Silver and Roberto Patricio Korzeniewicz for their feedback on earlier versions of the paper. 


\section{REFERENCES}

Amin, Samir. 1977. Imperialism \& Unequal Development. New York: Monthly Review Press. Arrighi, Giovanni. 1994. The Long Twentieth Century. London: Verso.

- 2007. Adam Smith in Beijing. London: Verso.

Atkin, Michael. 1992. The International Grain Trade. Cambridge: Woodhead Publishing Limited.

Auty, Richard. 1993. Sustaining Development in Mineral Economies: The Resource Curse Thesis. London: Routledge.

- 2001. Resource Abundance and Economic Development. New York: Oxford University Press.

Bairoch, Paul. 1993. Economics and World History: Myths and Paradoxes. Chicago: University of Chicago Press.

Baran, P. 1957. The Political Economy of Growth. New York: Monthly Review Press.

Bunker, Stephen and Paul Ciccantell. 2005. Globalization and the Race for Resources. Baltimore: The Johns Hopkins University Press.

Cardoso, Fernando and Enzo Faletto. 1979. Dependency and Development in Latin America. Berkeley: University of California Press.

Cashin, Paul and John C. McDermott. 2002. "The Long-run Behavior of Commodity Prices: Small Trends and Big Variability." IMF Staff Papers 49(2): 175-199.

Chandler, Alfred D., Jr. 1990. Scale and Scope: the Dynamics of Industrial Capitalism. Cambridge: The Belknap Press of Harvard University Press.

Corden, W. Max. 1984. "Booming Sector and Dutch Disease Economics: Survey and Consolidation." Oxford Economic Papers 36(3): 359-380.

Corden, W. Max and J. Peter Neary. 1982. "Booming Sector and De-industrialization in a Small Open Economy." Economic Journal 92: 825-848.

Cypher, J.M. and J.L. Dietz. 2004. The Process of Economic Development. $2^{\text {nd }}$ ed. New York: Routledge.

Ellison, Thomas. [1886] 1968. The Cotton Trade of Great Britain. London: Frank Cass \& Co.

Farnie, Douglas Anthony. 1979. The English Cotton Industry and the World Market: 1815-1896. Oxford: Oxford University Press.

Frank, Andre Gunder. 1969. Capitalism and Underdevelopment in Latin America. New York: Monthly Review Press.

Furtado, C. 1964. Development and Underdevelopment. Translated by Ricardo W. DeAguiar and Eric Charles Drysdal. Berkeley: University of California Press.

Grilli, Enzo and Maw Cheng Yang. 1988. "Primary Commodity Prices, Manufactured Goods Prices, and the Terms of Trade of Developing Countries: What the Long Run Shows." The World Bank Economic Review 2(1): 1-47.

Humphreys, Macartan, Jeffrey D. Sachs, and Joseph E. Stiglitz. 2007. Escaping the Resource Curse. New York: Columbia University Press.

Hobsbawm, Eric. 1975. The Age of Capital: 1848-1875. New York: Vintage Books.

- 1987. The Age of Empire: 1875-1914. New York: Vintage Books.

Imlah, A. H. 1950. "Terms of Trade of the United Kingdom, 1798-1913." Journal of Economic History 10: 170-94. 


\section{JOURNAL OF WORLD-SYSTEMS RESEARCH}

1958. Economic Elements in the Pax Britannica: Studies in British Foreign Trade in the Nineteenth Century. Cambridge: Harvard University Press.

International Monetary Fund. 2006. World Economic Outlook 2006. Washington, D.C.: International Monetary Fund.

—. 2011. World Economic Outlook 2010 Database. 2010. Retrieved May 2011 (http://www.imf.org/external/pubs/ft/weo/2010/).

Johnson, Chalmers. 2004. The Sorrows of Empire. New York: Metropolitan Books.

Kaplinsky, Raphael. 2010. "China, Commodity Prices and the Terms of Trade." Pp. 91-112 in China and the World Economy, edited by Chris Milner, Shujie Yao, and David Greenaway. New York: Palgrave Macmillan.

Karl, Terry Lynn. 1997. The Paradox of Plenty: Oil Booms and Petro-States. Berkeley: University of California Press.

Kramer, Andrew. 2011. "In Rebuilding Iraq's Oil Industry, U.S. Subcontractors Hold Sway." New York Times, June 17.

Maddison, Angus. 2006. The World Economy. Vol. 2, Historical Statistics. Paris: OECD.

Maizels, Alfred, Theodosios B. Palaskas, and Trevor Crowe. 1998. "The Prebisch-Singer Hypothesis Revisited." Pp. 63-85 in Development Economics and Policy: The Conference Volume to Celebrate the 85th Birthday of Professor Sir Hans Singer, edited by David Sapsford and John-ren Chen. New York: St. Martin's Press.

Matthews, Robert Guy. 2008. "Rio Tinto and BHP Push the cost of Iron Ore Higher." Wall Street Journal, June 24.

McMichael, Philip. 2004. Development and Social Change: A Global Perspective. $3^{\text {rd }}$ ed. Thousand Oaks, CA: Pine Forge Press.

Mitra, Pradeep. 1994. Adjustment in Oil-importing Countries: A Comparative Economic Analysis. Cambridge: Cambridge University Press.

Organization of Economic Cooperation and Development. 2010. SourceOECD Database.

Philip, George D. E. 1994. The Political Economy of International Oil. Edinburgh: Edinburgh University Press.

Prebisch, Raul. 1950. The Economic Development of Latin America and its Principal Problems. New York: United Nations.

Ricardo, David. 1821. On the Principles of Political Economy and Taxation. London: John Murray.

Ross, Michael. 2001. Timber Booms and Institutional Breakdown in Southeast Asia. Cambridge: Cambridge University Press.

Rosser, Andrew. 2007. "Escaping the Resource Curse: The Case of Indonesia." Journal of Contemporary Asia 37(1): 38-58.

Sachs, Jeffrey D. and Andrew Warner. 1995. "Natural Resource Abundance and Economic Growth." National Bureau of Economic Research Working Paper 5398. . 1997. "Sources of Slow Growth in African Economies." Journal of African Economics 6(3): 335-76 .

1999. "The Big Push, Natural Resource Booms and Growth." Journal of Development Economics 59: 43-76.

Sarkar, Prabirjit. 1986. "The Terms of Trade Experience of Britain Since the Nineteenth Century." Journal of Development Studies 23(1): 20-39. 
Sautman, Barry and Yan Hairong. 2007. "Friends and Interests: China's Distinctive Links with Africa." African Studies Review 50(3): 75-114.

Silver, Beverly and Giovanni Arrighi. 2003. "Polanyi's 'Double Movement': The Belle Époques of British and US Hegemony Compared." Politics \& Society 31(2): 325-55.

Singer, Hans. 1950. "U.S. Foreign Direct Investment in Underdeveloped Areas: The Distribution of Gains Between Investing and Borrowing Countries." American Economic Review 40(2): 473-85.

Smith, George Otis. 1919. The Strategy of Minerals. New York: D. Appleton and Company.

Taylor, Ian. 2006. "China's Oil Diplomacy in Africa." International Affairs 82(5): 937-59.

- 2009. China's New Role in Africa. Boulder, CO: Lynne Rienner Publishers, Inc.

The House of Commons. 1840. Report from the Select Committee on Import Duties with the minutes of evidence, an appendix, and index. House of Commons Parliamentary Papers. Retrieved April 15, 2010 (http://parlipapers.chadwyck.co.uk/marketing/index.jsp)

Tornell, A. and Philip Lane. 1999. "The Voracity Effect." American Economic Review 89(1): 2246.

United Nations Conference on Trade and Development. 2007. World Investment Report 2007: Transnational Corporations, Extractive Industries and Development. Geneva and New York: United Nations Press.

Winders, Bill. 2009. "The Vanishing Free Market: The Formation and Spread of the British and US Food Regimes." Journal of Agrarian Change 9(3): 315-44.

Wonacott, Peter. 2011. "U.S. Aims to Gain New Edge in Africa." Wall Street Journal, June 11.

Wright, Gavin. 1990. "The Origins of American Industrial Success, 1879-1940." The American Economic Review 80(4): 651-68 .

Wright, Gavin, and Jesse Czelusta. 2007. "Resource-Based Growth Past and Present." Pp. 183212 in Neither Curse nor Destiny: Natural Resources and Development, edited by Daniel Lederman and William Maloney. Palo Alto, CA: Stanford University Press and World Bank. 